\title{
Relationship of foraminiferal abundance with the trophic conditions in a marine coastal area of western India
}

\author{
Amrutha Avilavalappil ${ }^{1,2}$, Rajashekhar K. Patil ${ }^{2}$, Somashekarappa Hiriyur Mallaiah ${ }^{1}$ \\ ${ }^{1}$ Centre for Application of Radioisotopes and Radiation Technology (CARRT), Mangalore University, Mangalore 574199, \\ Karnataka, India. E-mail: amrucarrt@gmail.com \\ ${ }^{2}$ Department of Applied Zoology, Mangalore University Mangalore 574199, Karnataka, India.
}

\begin{abstract}
Summary: Surface seawater and sediment parameters indicate the trophic state of coastal marine systems. We used a biochemical approach to identify descriptors of the trophic state and environmental quality of intertidal ecosystems, based on the analysis of the quality and quantity of sedimentary organic matter, water nutrients and their correlation with the foraminiferal population at two sites on the west coast of India. Surface intertidal sediments were collected for a period of 17 months from January 2012 to May 2013 at intervals of two months by using a short core tube. Total foraminiferal number and live foraminiferal number showed a peak during the post-monsoon period, when there is an enrichment of sediment chlorophyll $a$ as well as a dominance of carbohydrates over sedimentary protein. Thus, a small change in the trophic status of the environment from a lower oligotrophic to a higher oligotrophic condition is responsible for the enhancement of foraminiferal population and diversity in the study sites. In particular, sediment protein concentration appeared to be a good descriptor of the trophic state. A gradual increase in foraminiferal population from a protein-rich, fresh organic matter environment to a carbohydrate-rich, detritus organic matter environment indicates the foraminiferal preference for detritus food sources. Thus, the main regulation factor for abundance and diversity of foraminifera at the study sites is trophication.
\end{abstract}

Keywords: Foraminifera; trophic state; organic matter composition.

Relación entre la abundancia de foraminíferos y las condiciones tróficas de la zona marino-costera, al oeste de la India

Resumen: Los parámetros del agua de mar superficial y del sedimento son indicadores del estado trófico de los sistemas marinos costeros. Hemos usado una aproximación bioquímica para identificar los descriptores del estado trófico y calidad ambiental de los ecosistemas intermareales, basado en el análisis de la calidad y la cantidad de materia orgánica sedimentaria, de los nutrientes del agua y su correlación con la población de foraminíferos en dos lugares de la costa oeste de la India. Las muestras de la superficie de los sedimentos intermareales se recogieron durante un período de diecisiete meses desde enero de 2012 a mayo de 2013, a intervalos de dos meses mediante el uso de un corer. El número total de foraminíferos (TFN), así como el número de foraminiferos vivos (LFN) mostró un pico durante el periodo posterior al monzón cuando se produce un enriquecimiento de clorofila $a$ en el sedimento y un dominio de la concentración de hidratos de carbono sobre la de las proteínas sedimentarias. Por tanto, un cambio pequeño en el estado trófico del medio ambiente desde condiciones de menos a más oligotróficas son responsables de la mejora de la población y la diversidad de foraminíferos en los sitios de estudio. En particular, la concentración de proteína del sedimento resultaba ser un buen descriptor del estado trófico del sistema. Un incremento gradual de la población de foraminíferos desde un ambiente rico en proteínas y materia orgánica fresca a uno rico en carbohidratos y materia orgánica detrítica indica que los foraminíferos prefieren las fuentes de alimento de detritus. Así, el factor de regulación principal para la abundancia y diversidad de foraminíferos se debe al distinto grado trófico del sistema.

Palabras clave: Foraminíferos; estado trófico; composición de materia orgánica.

Citation/Como citar este artículo: Avilavalappil A., Patil R.K., Mallaiah S.H. 2014. Relationship of foraminiferal abundance with the trophic conditions in a marine coastal area of western India. Sci. Mar. 78(3): 389-396. doi: http://dx.doi org/10.3989/scimar.03945.16B

Editor: D. Vaqué.

Received: August 31, 2013. Accepted: April 28, 2014. Published: July 16, 2014.

Copyright: @ 2014 CSIC. This is an open-access article distributed under the Creative Commons Attribution-Non Commercial Lisence (by-nc) Spain 3.0.

\section{INTRODUCTION}

Single-celled protists play an important role in marine food webs (Anderson 1994). Foraminifera are among the most abundant known protists found in marine habitats and show broad ecological adaptability (Lipps 1983). These single-celled organisms can exist in nearly all marine environments, including deep-sea 
areas and extreme ecosystems (Gooday 1992, Linke and Lutze 1993). They are characterized by a short life cycle (when compared with macrofaunal metazoans) and react rather quickly to both short and long-term changes in marine and estuarine environments. For these reasons, foraminifera are used increasingly to evaluate the environmental status of marine coastal systems impacted by pollution and eutrophication (Frontalini and Coccioni 2012, Nigam et al. 2006).

The foraminiferal populations in marine sediments are mainly constrained by fluxes of organic particles (Gooday 2003). These organic fluxes are in turn strongly influenced by surface ocean productivity (Altenbach et al. 1999). During the last few decades several ecological studies of benthic foraminifera indicate the importance of organic matter fluxes as the main parameter controlling the populations of deep-sea benthic foraminifera. The marginal marine environments are highly "stressed", showing a larger number of factors that can play a major role (i.e. temperature, salinity, sediment, toxic substances, as well as biological interactions; Murray 1991, 2001, Jorissen et al. 2007). During the last years two factors have been invoked to explain benthic foraminifera distribution and abundance in marginal environments: sediment grain-size and organic matter (OM) quantity and quality (Debenay et al. 2001, Diaz et al. 2004, Schafer et al. 1991, 1995, Setty and Nigam 1982, Alve 1991), both of which have controversial and complex effects on foraminiferal populations.

The trophic state of marine sediments is dependent not only upon the absolute quantities of the OM deposited on the sea floor but also on its biochemical composition and nutritional quality (Pusceddu et al. 2009). Foraminifera are prey for many marine invertebrates and vertebrates (such as holothuroids, deep-sea scaphopods and coral reef fish), and are the chief food source for some of them (Lipps 1983, 1988). Thus, benthic foraminifera are a link between low and high trophic levels and are important in the cycling of OM and organic carbon (Gooday 1992). Studies on the role of the biochemical composition and the nutritional quality of the sediment OM in the ecology of foraminifera is limited. Sedimentary OM consists of labile and refractory compounds. The labile (i.e. readily available) fraction of sedimentary OM controls distribution of benthic communities in lagoons and marine shallow environments (Pusceddu et al. 2007). In particular, sediment protein and carbohydrate concentrations appear to be good descriptors of the trophic state of the benthic system, as demonstrated by Dell' Anno et al. (2002).

The present study aims 1) to assess the trophic status using descriptors in surface sediments and water parameters combined with foraminiferal population; and 2) to understand how seasonal changes in the quality and quantity of sedimentary food resources affect foraminiferal population in the intertidal sediments of the west coast of India.

In order to address these questions, we studied the abundance and biodiversity of living (as Rose-Bengal positive) intertidal foraminifera together with the quantity and biochemical composition of the sediment
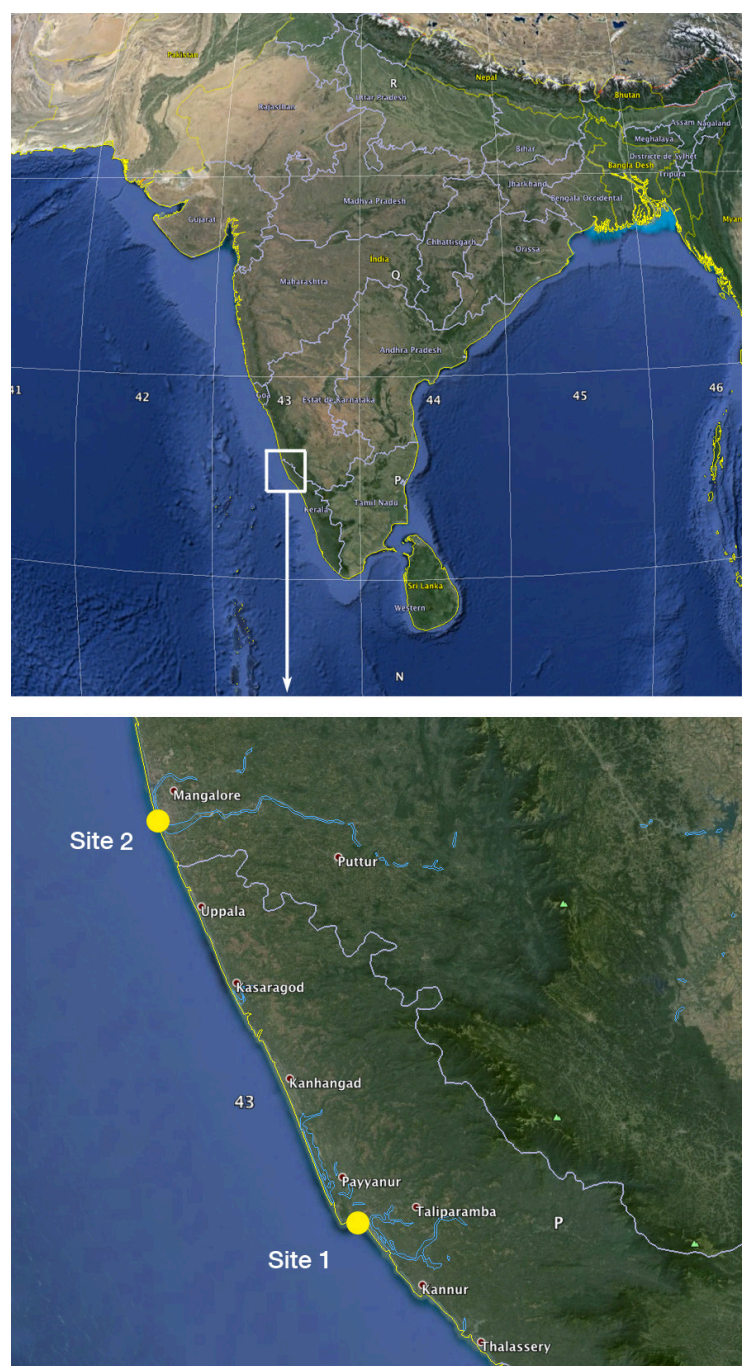

Fig. 1. - Map of study sites (Site 1, Payyannur; Site 2, Panambur) (Source: http//www.google.com/earth/index.html)

in terms of OM, carbohydrate content, protein content and chlorophyll $a(\mathrm{Chl} a)$ content as well as surface seawater in terms of primary nutrients such as nitrate, nitrite, phosphate, reactive silicate and $\mathrm{Chl} a$ on the west coast of India.

\section{METHODOLOGY}

\section{Study area}

The present study was carried out in Payyannur $\left(12^{\circ} 0^{\prime} \mathrm{N}, 7^{\circ} 12^{\prime} \mathrm{E}\right.$; Site 1$)$ and Panambur $\left(12^{\circ} 57^{\prime} \mathrm{N}\right.$, $74^{\circ} 48^{\prime} \mathrm{E}$; Site 2 ) on the west coast of India (Fig. 1). The shoreline is generally straight and is low-lying and sandy. The southern west coast of India has narrow coastal plains bordered on the east by Western Ghats. The rivers originating from Western Ghats provide large inputs of various micro and macro nutrients to the open sea. The monsoon thus considerably alters the hydrobiologic profile of the Arabian Sea, triggering seasonal reversals in the surface circulation and a high Chl $a$ concentration and low salinity (Bhattathiri et al. 1996, Wiggert et al. 2005) during the Southwest Monsoon, which leads to one of the highest production rates 
in the world. Seasonal and regional changes of surface water productivity and the variability of organic carbon fluxes make this study site ideal to investigate the impact of food resources and trophic status on foraminiferal abundance and diversity.

\section{Sample collection and processing (Foraminifera)}

Intertidal sediments were collected for a period of 17 months from January 2012 to May 2013 at intervals of two months. A short core tube was pushed into the sediment to a depth of around $5 \mathrm{~cm}$ for the collection of sediment samples. The surface sediments were analysed for foraminiferal diversity and abundance in relation to the quality and quantity of food resources of the intertidal sediment (in terms of OM, carbohydrate content, protein content and $\mathrm{Chl} a$ ). The top $1 \mathrm{~cm}$ of the surface sediment was collected, preserved in $70 \%$ alcohol and stained with Rose Bengal (overnight) to identify live organisms. Rose Bengal is routinely used to differentiate living from dead foraminifera (Walton 1952, Scott and Medioli 1980, Murray 1991). Protoplasm is stained bright red whereas test walls and organic lining are either unstained or lightly stained. The advantages are that no special equipment is required and it is quick. It is thus ideal for large number of samples. The disadvantage is that clumps of bacteria inside the test or cyanobacteria or fungi on the outside may be mistaken for protoplasm or that the stain may not be taken up if the individual is starving. We assumed that tests containing protoplasm within the last few chambers were living at the time of collection (Murray and Alve 1999, Horton et al. 1999). Sediment samples were wet-sieved through a $63-\mu \mathrm{m}$ mesh screen and dried. All stained (total life assemblage) and unstained (dead) Foraminifera (Murray and Browser 2000) were picked under binocular, then identified and counted. The total foraminiferal number (TFN) and live foraminiferal number (LFN) in each sample were computed and standardised to $1 \mathrm{~g}$ dry sediment. The species were identified and classified by following Loeblich and Tappan (1987).

\section{Sample collection and analysis (sediment geochem- ical and sea water parameter)}

For the analysis of nutrients, surface water samples (1 L) were collected in clean polypropylene/glass containers, placed in an ice box and transported immediately to the laboratory from the study sites. Chl $a$ was analysed according to Lorenzen and Jeffrey (1980). Pigments were extracted with $90 \%$ acetone $(24 \mathrm{~h}$ in the dark at $\left.4^{\circ} \mathrm{C}\right)$. Following centrifugation, the supernatant was used to determine functional Chl $a$. Sediment carbohydrates were extracted in concentrated $\mathrm{H}_{2} \mathrm{SO}_{4}$ and measured according to Dubois et al. (1956). Absorbance was measured at $490 \mathrm{~nm}$ using a SICAN 2301 UV-VIS spectrophotometer. Solutions of D (+)-glucose were used as standards. Sediment proteins were extracted in $1 \mathrm{~N} \mathrm{NaOH}$ and were estimated according to Lowry's Method (Lowry et al. 1951). Absorbance was measured at $650 \mathrm{~nm}$ with a SICAN 2301 UV-VIS spectrophotometer. Bovine albumin solutions were used as standards. The values of protein to carbohydrate ratio as descriptors of the ageing and nutritional quality of sediment OM were calculated (Pusceddu et al. 2010, 2011). The seawater samples were filtered and analysed for inorganic phosphate, nitrate, nitrite and reactive silicate by adopting the standard methods described by Strickland and Parsons (1972).

\section{Biodiversity analysis (Foraminifera)}

Foraminiferal biodiversity was analysed using the following diversity indices: species richness (S) measured as the number of species; dominance (D) measured by the 1-Simpson Index; species diversity $(\mathrm{H}$ loge) measured by the Shannon-Wiener $(\mathrm{H})$ information function; and species evenness $(\mathrm{J})$ measured using the Pielou Index. All indices were calculated using PAST software (Hammer et al. 2001).

\section{Statistical analysis}

Statistical analysis was carried out using IBM SPSS 20 statistical software (SPSS Inc, Chicago, IL, USA).

\section{RESULTS}

\section{Foraminiferal abundance and species richness}

Figure 2 shows clear seasonality in TFN and LFN per gram sediment. TFN varied from 3 to 529 per gram sediment at Site 1 and 4 to 652 per gram sediment at Site 2. LFN varied from 3 to 204/g and from 0 to 256/g at Sites 1 and 2, respectively. The results of analysis of variance (ANOVA) for the difference in TFN between the stations were not significant. The highest densities and diversities were observed during the post-monsoon period (October to December) rather than the monsoon period (June to september) and pre-monsoon period (March to May) at both sites.

The benthic foraminifera assemblages analysed can be grouped into two orders (Rotaliina and Miliolina) and seven families (Rotaliidae, Spiroloculinidae, Rosalinidae, Hauerinidae, Nonionidae, Elphidiidae, and Eponididae). The total number of species (live + dead) ranged from 1 to 13 (Site 1) and 1 to 15 (Site 2), and the species Rotallidium annectans, Ammonia dentate, Ammonia becarii and Pararotalia calcar were the most abundant. Rotallidium annectans were found to be the most dominant species with the highest percentage (Site 1, 94\%; Site 2, 75\%) of LFN at both sites.

The Shannon Index values were higher in March 2013 at Site $1\left(H^{\prime}=0.63\right)$ and January 2012 at Site 2 $\left(H^{\prime}=1.04\right)$. The highest Pielou evenness occured in May 2012 at Site 1 (0.94) and in January 2012 at Site 2 (0.94) and the lowest in November 2012 at both sites (Site 1-0.12; Site 2-0.15) (Table 1).

\section{Biochemical composition of sedimentary OM}

The organic carbon content in the study area varies from $0.09 \%$ to $0.16 \%$ at Site 1 and $0.07 \%$ to $0.19 \%$ at Site 2 (Fig. 3). The highest concentrations occurred in 
Total Foraminiferal Number(TFN)
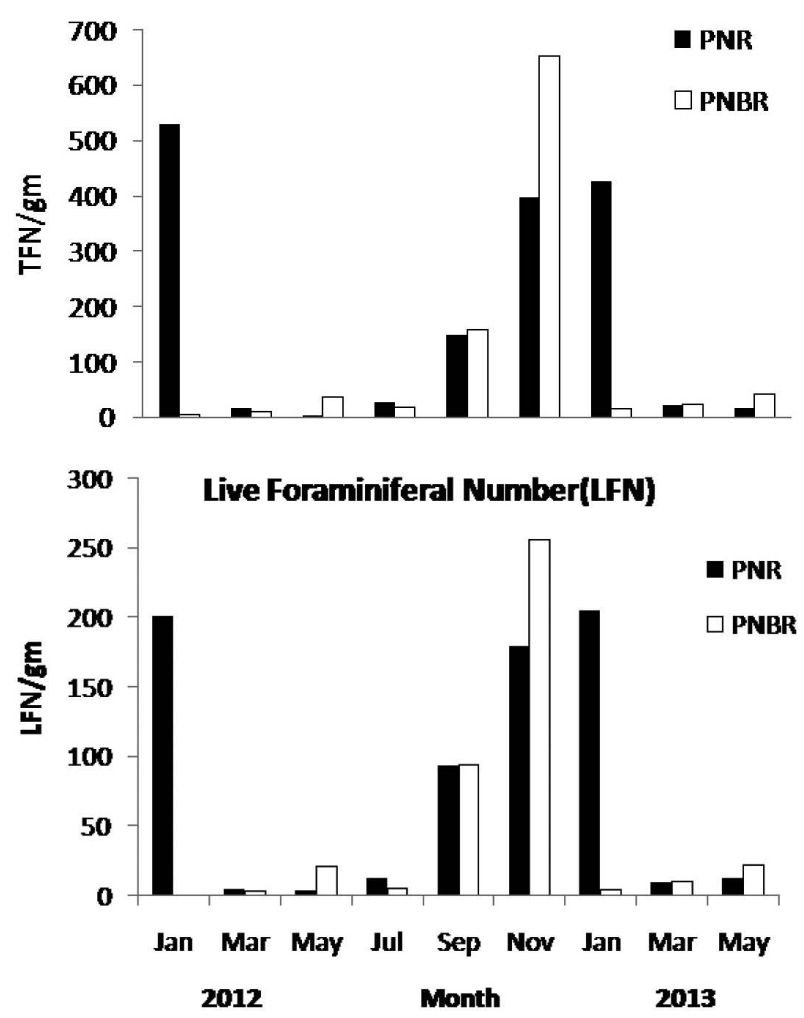

Fig 2. - A, total foraminiferal number, B, live foraminiferal number at Site 1, Payyannur (PNR), and Site 2, Panambur (PNBR).

January 2012 at Site 1 while at Site 2, where seasonality was more evident, the highest concentration was measured in November 2012. Lowest organic contents were measured in the monsoon season at both stations. TFN was positively correlated with the sediment OM at both sites ( $\mathrm{r}=0.63$ at Site $1 ; \mathrm{r}=0.71$ at Site 2). A good correlation was also observed between the LFN and sediment OM ( $r=0.59$ at Site $1 ; r=0.63$ at Site 2).

Sedimentary carbohydrates and proteins showed a strong seasonality (Fig. 4). Sedimentary carbohydrate ranged between 0.03 and $0.22 \mathrm{mg} \mathrm{g}^{-1}$ at Site 1 and 0.04 and $0.32 \mathrm{mg} \mathrm{g}^{-1}$ at Site 2. The highest carbohydrate content was observed in January 2013 at Site 1 and November 2012 at Site 2 . The proteins ranged between 0 and $0.02 \mathrm{mg} \mathrm{g}^{-1}$ at Site 1 and 0 and $0.03 \mathrm{mg} \mathrm{g}^{-1}$ at Site 2. The protein content was found to be below de-

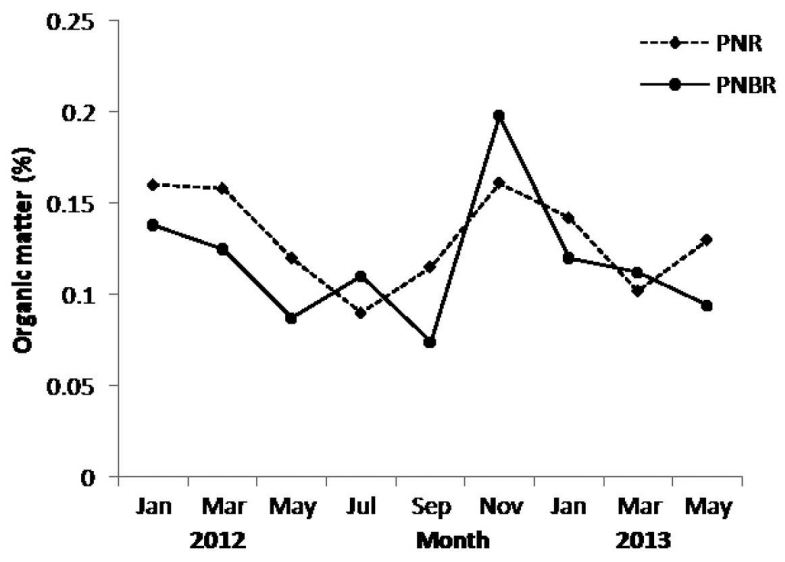

Fig. 3. - Percentage organic matter of the sediment at Site 1, Payyannur (PNR), and Site 2, Panambur (PNBR).
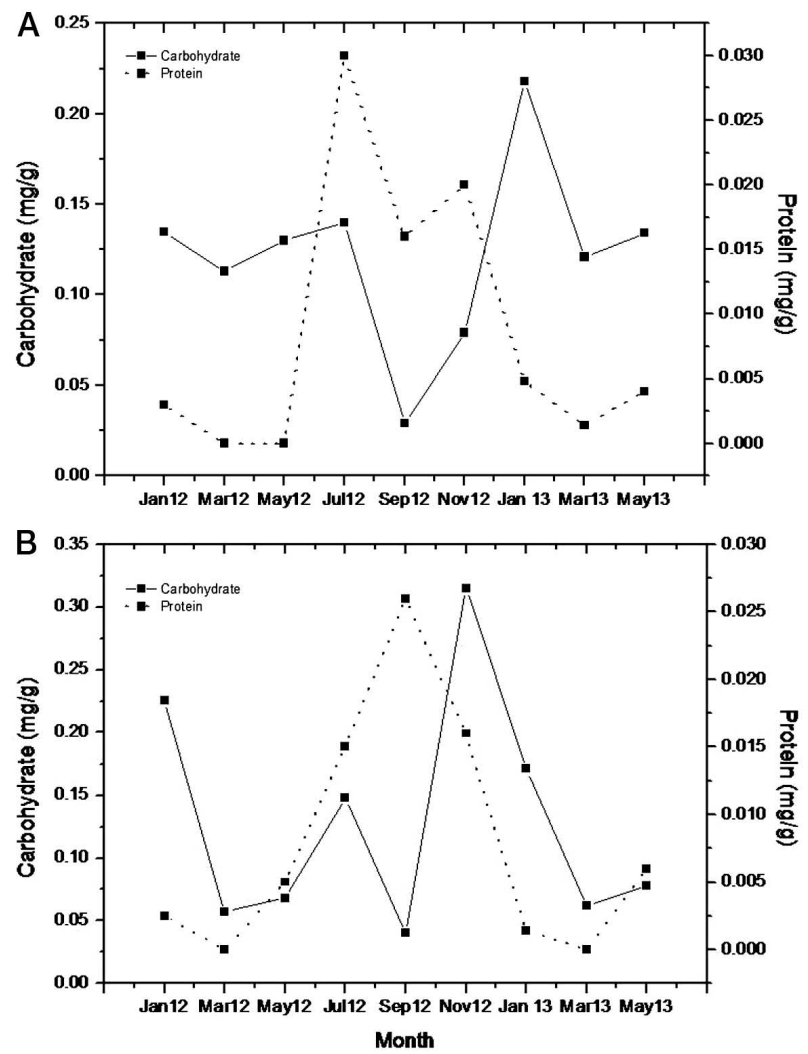

Fig. 4. - Seasonal variations of sedimentary carbohydrates (CHO) and proteins (PRT) at Site 1 (A), Payyannur (PNR) and Site 2 (B), Panambur (PNBR).

Table 1. - Diversity characteristics of the total foraminiferal population at Site 1, Payyannur (PNR) and Site 2, Panambur (PNBR).

\begin{tabular}{lcccccccccc}
\hline Species & & Jan 12 & Mar & May & Jul & Sep & Nov & Jan13 & Mar & May \\
\hline TFN /gm & Site 1 & 529 & 15 & 3 & 27 & 147 & 395 & 425 & 20 & 15 \\
& Site 2 & 4 & 11 & 38 & 19 & 158 & 652 & 18 & 24 & 44 \\
LFN/gm & Site 1 & 200 & 4 & 3 & 12 & 93 & 179 & 204 & 9 & 12 \\
& Site 2 & 0 & 3 & 21 & 5 & 94 & 256 & 4 & 10 & 22 \\
Dominance & Site 1 & 0.89 & 0.76 & 0.55 & 0.86 & 0.98 & 0.82 & 0.88 & 0.66 & 0.76 \\
& Site 2 & 0.37 & 0.68 & 0.67 & 0.90 & 0.97 & 0.81 & 0.62 & 0.84 & 0.91 \\
Shannon diversity (H') & Site 1 & 0.31 & 0.48 & 0.63 & 0.31 & 0.04 & 0.49 & 0.32 & 0.63 & 0.48 \\
& Site 2 & 1.04 & 0.60 & 0.83 & 0.20 & 0.07 & 0.47 & 0.68 & 0.34 & 0.21 \\
Simpson's dominance & Site 1 & 0.11 & 0.24 & 0.44 & 0.14 & 0.01 & 0.18 & 0.12 & 0.34 & 0.24 \\
& Site 2 & 0.62 & 0.31 & 0.32 & 0.09 & 0.02 & 0.18 & 0.37 & 0.15 & 0.08 \\
Eveness & Site 1 & 0.13 & 0.54 & 0.94 & 0.45 & 0.52 & 0.12 & 0.13 & 0.63 & 0.54 \\
& Site 2 & 0.94 & 0.60 & 0.28 & 0.61 & 0.35 & 0.15 & 0.66 & 0.47 & 0.41 \\
\hline
\end{tabular}




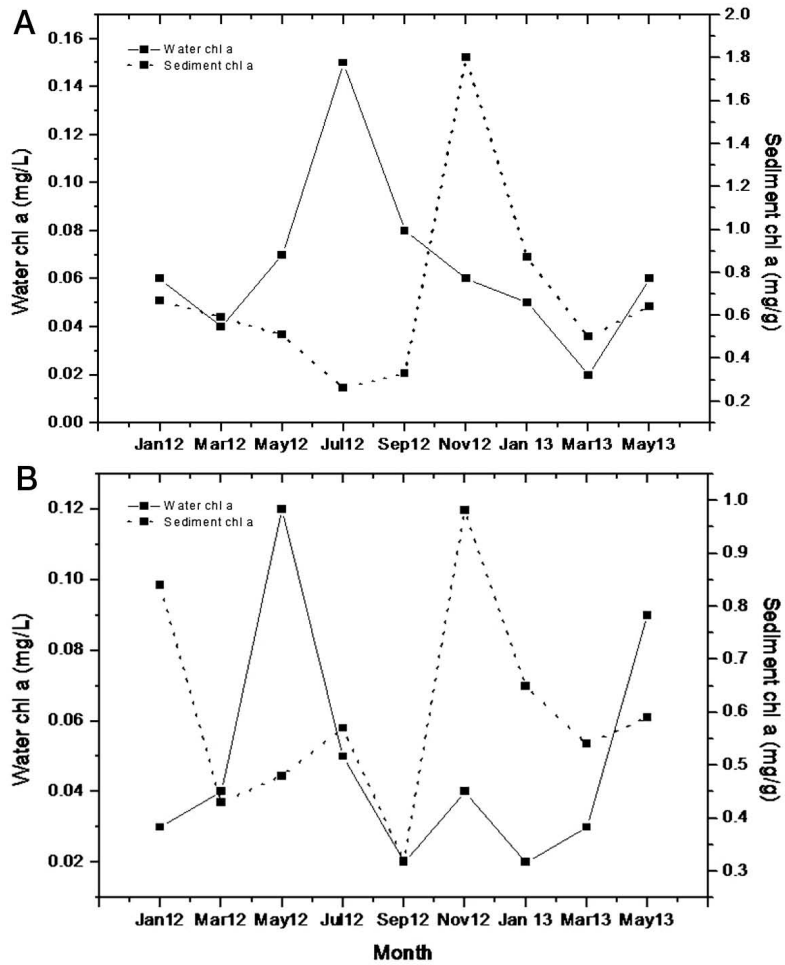

Fig. 5. - Seasonal variations in sediment chlorophyll $a$ and water chlorophyll $a$ at Site 1 (A), Payyannur (PNR) and Site 2 (B), Panambur (PNBR).

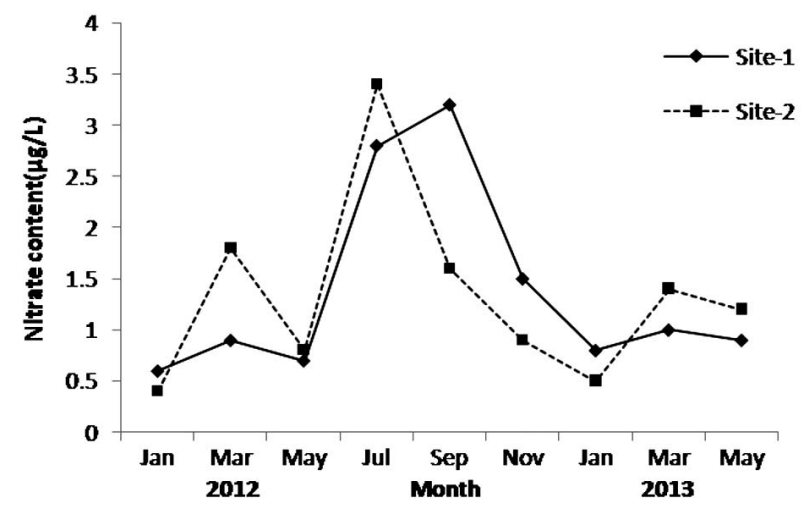

Fig. 6. - Seasonal variations in nitrate content of seawater at Site 1, Payyannur (PNR), and Site 2, Panambur (PNBR).

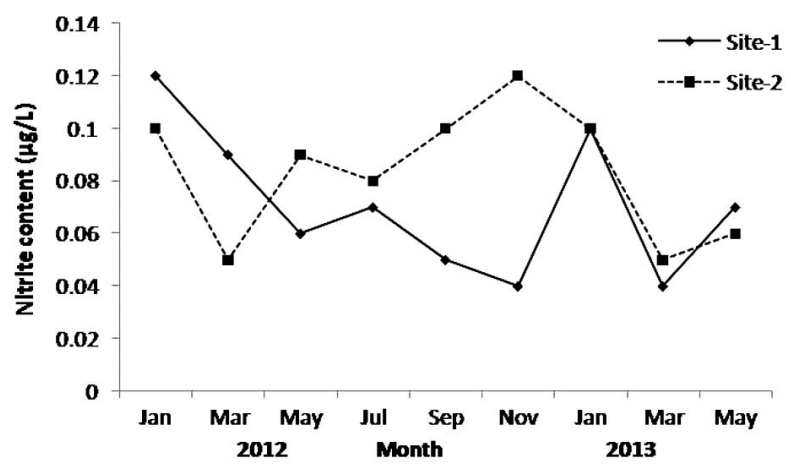

Fig. 7. - Seasonal variations in nitrite content of seawater at Site 1, Payyannur (PNR) and Site 2, Panambur (PNBR).

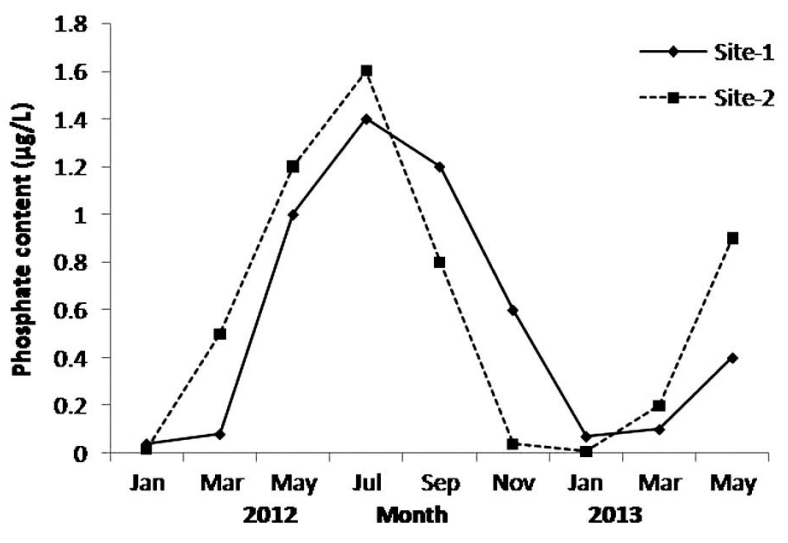

Fig. 8. - Seasonal variations in phosphate content of seawater at Site 1, Payyannur (PNR), and Site 2, Panambur (PNBR).

tectable level during the summer months at both sites. This finding may be due to the low organic inputs during the summer months. Protein to carbohydrate ratio (PRT: CHO) ranged between 0 to 0.6 and 0 to 0.7 at Sites 1 and 2, respectively. The highest PRT: CHO ratio was observed during the post-monsoon months and the lowest during the summer months at both sites.

Sedimentary Chl $a$ did not vary significantly among sites. It showed seasonality at both sites and values ranged between 0.26 and $1.84 \mathrm{mg} \mathrm{g}^{-1}$ at Site 1 and between 0.32 and $0.98 \mathrm{mg} \mathrm{g}^{-1}$ at Site 2. Peaks in water Chl $a$ preceded peaks in sediment Chl $a$ by about 60 days at both sites (Fig. 5). Significant positive correlation was observed between the sedimentary Chl $a$ and TFN ( $r=0.56$ at Site $1 ; r=0.57$ at Site 2 ). Similarly, the LFN also correlated positively with the sedimentary Chl $a(\mathrm{r}=0.58$ at Site $1 ; \mathrm{r}=0.5$ at Site 2$)$ at both sites.

\section{Seawater trophic parameters}

The primary nutrients were found to be higher during the monsoon season. Nitrate concentration varied from 0.6 to $3.2 \mu \mathrm{g} \mathrm{L}^{-1}$ at Site 1 and from 0.4 to $3.4 \mu \mathrm{g}$ $\mathrm{L}^{-1}$ at Site 2 (Fig. 6). Nitrite content was ranged from 0.07 to $0.12 \mu \mathrm{g} \mathrm{L}^{-1}$ at Site 1 and from 0.05 to $0.12 \mu \mathrm{g}$ $\mathrm{L}^{-1}$ at Site 2 (Fig. 7). Inorganic phosphorous ranged from 0.04 to $1.4 \mu \mathrm{g} \mathrm{L} \mathrm{L}^{-1}$ and from 0.01 to $1.6 \mu \mathrm{g} \mathrm{\textrm {L } ^ { - 1 }}$ at Sites 1 and 2, respectively (Fig. 8). Reactive Silicate

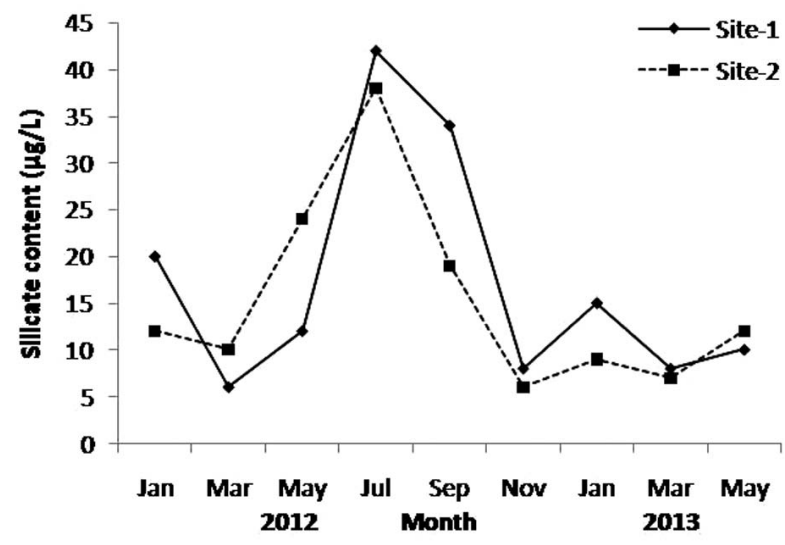

Fig. 9. - Seasonal variations in reactive silicate of seawater at Site 1, Payyannur (PNR), and Site 2, Panambur (PNBR). 
was found to be between 6 and $42 \mu \mathrm{g} \mathrm{L}^{-1}$ at Site 1 and between 6 and $38 \mu \mathrm{g} \mathrm{L}^{-1}$ at Site 2 (Fig. 9).

\section{DISCUSSION}

\section{Influence of seawater circulation and sediment parameters on trophic status}

Chlorophyll $a$ is considered the principal indicator of trophic state as well as an index for biomass of primary producers. The present study area shows episodic peaks in water Chl $a$ as well as sediment $\mathrm{Chl} a$, with a time lag of about 60 days. Upwelling delivers a considerable amount of nutrient load as well as organic detritus to the area, leading to modification of the trophic status of the environment. Deposition of organic material from the water may cause increases in benthic OM rapidly at timescales of weeks but may persist for several months. In the present study the sediment $\mathrm{Chl} a$ concentration was much higher than the water column Chl $a$ concentration, suggesting rapid sedimentation and incorporation of phytoplankton into surface sediments, and that peaks in sedimentary $\mathrm{Chl} a$ followed the peaks of Chl $a$ in the water column by about 60 days (Fig. 5)

Carbohydrates are the principle organic compounds produced by autotrophic organisms by photosynthesis, being part of the structural and reserve tissues of aquatic and terrestrial plants. Also, microphytobenthos produces large amounts of exocellular carbohydrates mostly derived from metabolic activity in response to variations in light intensity, nutrient availability, salinity and taxonomic composition of the biofilm (Welker et al. 2002). Therefore, the carbohydrate content in sediments may originate from several sources, such as sedimentation of planktonic microalgae, benthic primary production and riverine input of terrestrial compounds. Protein concentrations in sediments reflect the productivity of the system, as they are indicative of microalgal biomass and mobilize more rapidly than carbohydrates, which are more refractory (Danovaro et al. 1999). In the present study the enrichment of sediment by protein during the monsoon season appears to indicate the presence of recently produced OM, but also a high amount of partially degraded organic material derived from both primary production and anthropogenic sources. By a time lag of 30-60 days the composition of sedimentary OM shows a dominance of carbohydrates over proteins. The dominance of carbohydrates over proteins is a characteristic feature of higher oligotrophic or detrital environments (Danovaro 1993). The protein to carbohydrate (PRT: CHO) ratio can also give some information about the quality of this sediment OM: the higher the protein to carbohydrate ratio, the fresher the organic material (Pusceddu et al. 2000, 2011). In the present study a low PRT:CHO suggests the presence of aged OM (Danovaro 1996). No significant seasonal or spatial changes were found in PRT:CHO ratio in our study area. For most of the study period, the ratio remained below 1.0. This confirms that the sediments of the study sites were characterized by a large amount of non-living OM. Sediment protein and carbohydrate concentrations appear to be good de- scriptors of the trophic state of the benthic system, as demonstrated by Dell' Anno et al. (2002).

\section{Influence of quantity and nutritional quality of sedimentary OM in the foraminiferal population}

Foraminifera require food in order to grow and reproduce (Myers 1943). Phytodetritus, derived either from decaying microphytobenthos or settled phytoplankton, is universally considered one of the most important food sources for the sediment-dwelling benthos (Pusceddu et al. 2003). Also, organic N, and therefore primarily proteins, are considered the most important limiting factor for heterotrophic nutrition (Fabiano et al. 1995). Previous studies have documented links between benthic foraminiferal populations and cycles in food supply and levels of OM, and have found evidence that benthic foraminifera are efficient at quickly exploiting food resources, in both shallow and deep water environments (Buzas 1969, Lee and Muller 1973). Foraminiferal populations have been shown to increase in response to blooms in primary production (Alve and Murray 1994). TFN and LFN exhibit seasonal cycles similar to those of sediment OM levels (Devi and Rajashekhar 2009) on the west coast of India. Fluctuations in benthic foraminiferal populations in these coastal sediments appear to be closely tied to cycles in food resources.

Many researchers have investigated the correlation between foraminiferal populations and sediment total organic carbon (TOC), but some have found poor correlation between foraminiferal abundance and organic carbon (Setty and Nigam 1982, Qvale and Van Weering 1985). Altenbach and Sarnthein (1989) and Murray and Alve (2000) proposed sediment Chl $a$ as a best proxy for food supply.

Some studies have measured multiple potential food resources, including sediment amino acids (Kroencke et al. 2000). Many different food sources and feeding strategies have been reported for benthic foraminifera, including selective ingestion of bacteria, deposit and suspension feeders, detritivory and scavenging (Lipps 1983, Goldstein and Corliss 1994). Therefore, a wide range of OM types are potential food resources for benthic foraminifera, and different types of food are probably important to benthic foraminifera in different marine environments.

The present study shows the differences in foraminiferal abundance and biodiversity with the quantity and nutritional quality of sedimentary OM during the postmonsoon period. The increased nutrient load into the coastal waters will increase the primary productivity, which will further increase the rapid reproduction of the foraminiferal population (Fig. 10). Therefore, a positive relation can be seen between the foraminiferal population and the water nutritional parameters.

\section{Foraminiferal population and trophic status}

The TFN and LFN showed a peak during the post-monsoon period, when there is an enrichment of sediment $\mathrm{Chl} a$ and a dominance of carbohydrates 

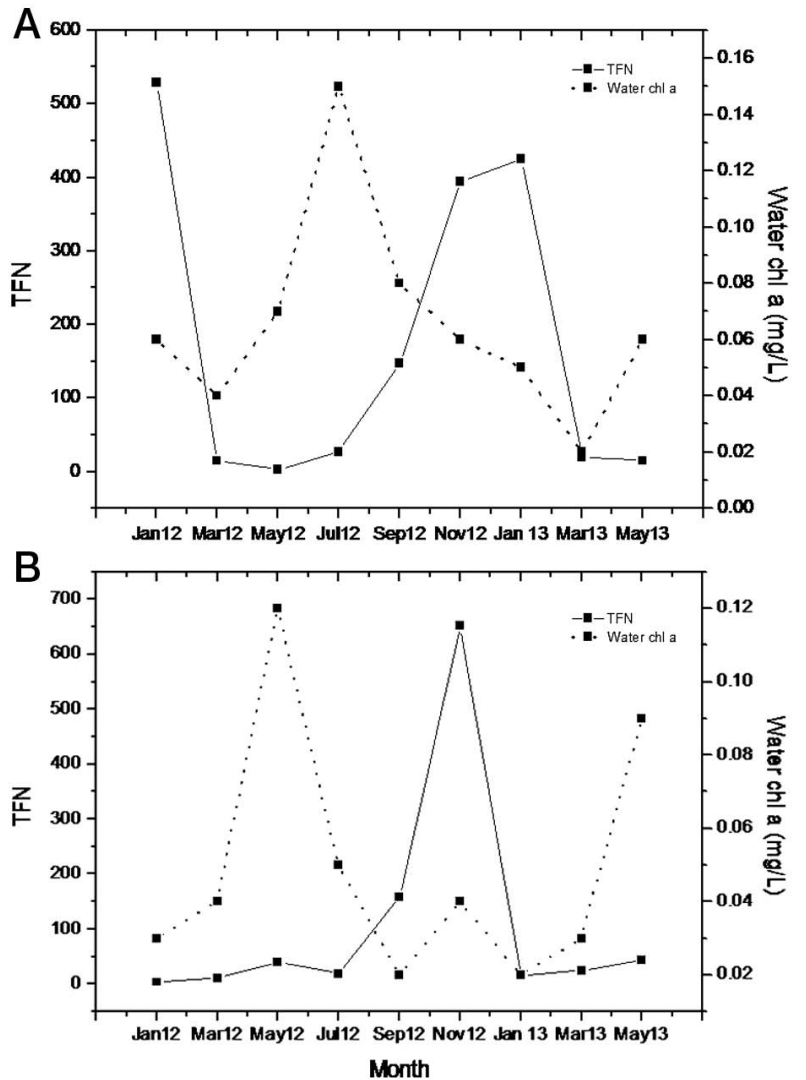

Fig. 10. - Seasonal variations in water chlorophyll $a$ and total foraminiferal number (TFN/g) at Site 1 (A), Payyannur (PNR) and Site 2 (B), Panambur (PNBR)

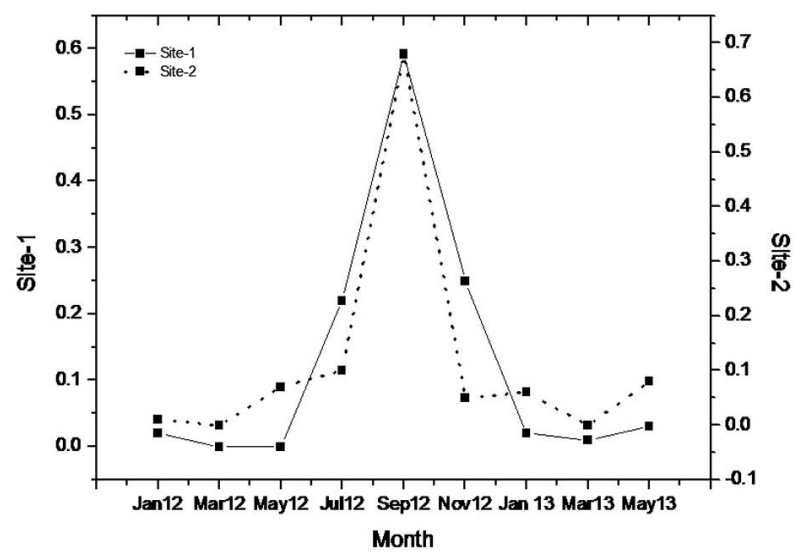

Fig. 11. - Protein/carbohydrate ratio at Site 1, Payyannur (PNR) and Site 2, Panambur (PNBR).

over sedimentary protein (Fig. 4). The study areas are characterized by oligotrophic conditions and a small change in the trophic status of the environment from a lower oligotrophic to a higher oligotrophic condition is responsible for the enhancement of foraminiferal population and diversity at the study sites. Upwelling leads to occurrence of a protein-rich environment with nutrient and $\mathrm{Chl} a$. The decrease in foraminiferal population during the monsoon season indicates less favourable environmental and trophic conditions. A gradual increase in foraminiferal population from a protein-rich fresh OM environment to a carbohydrate-rich detritus $\mathrm{OM}$ environment indicates the foraminiferal prefer- ence of detritus food sources, which also supports the protein-carbohydrate data used to characterize the study areas as a detritus environment. Figure 11 shows a gradual decrease in the protein to carbohydrate ratio below 0.1 during the post-monsoon period, which also supports the hypothesis of the higher oligotrophic condition (Pusceddu 1997). The main regulation factor for abundance and diversity of foraminifera is trophication. Thus, the peaks in foraminiferal population and diversity during these periods indicate the foraminiferal preference for a higher oligotrophic environmental condition.

\section{ACKNOWLEDGEMENTS}

The first author (Amrutha) is grateful to the Department of Science and Technology (DST), New Delhi for the financial support to carry out the study under the INSPIRE Programme. The author used the research facility at the Centre for Application of Radioisotopes and Radiation technology (CARRT), Mangalore University, for the present study.

\section{REFERENCES}

Altenbach A.V., Sarnthein M. 1989. Productivity record in benthic foraminifera. In: Berger, W.H., Smetacek, V.S., Wefer, G. Chichester (ed.). Productivity of the ocean: present and past. New York, John Wiley and Sons, pp. 255-269.

Altenbach A.V., Pflaumann U., Schiebel R., et al. 1999. Scaling percentages and distributional patterns of benthic foraminifera with flux rates of organic carbon. J. Foram. Res. 29: 173-185.

Alve E. 1991.Benthic foraminifera in sediment cores reflecting heavy metal pollution in Sorfjord, western Norway. J. Foraminif. Res. 21: 1-19. http://dx.doi.org/10.2113/gsjfr.21.1.1

Alve E, Murray J.W. 1994. Ecology and taphonomy of benthic foraminifera in a temperate mesotidal inlet. J. Foraminif. Res. 24: 18-27. http://dx.doi.org/10.2113/gsjfr.24.1.18

Anderson O.R.1994. The trophic role of planktonic foraminifera and radiolaria. Mar. Microb. Food Webs 7: 31-51.

Bhattathiri P.M., Pant A.A., Sawant S., et al. 1996. Phytoplankton production and chlorophyll distribution in the eastern and central Arabian Sea in 1994-1995. Curr. Sci. 71: 857-862.

Buzas M.A. 1969. Foraminiferal species densities and environmental variables in an estuary. Limnol. Oceanogr. 41: 411-422. http://dx.doi.org/10.4319/1o.1969.14.3.0411

Danovaro R. 1993. Analisi della dinamica e struttura trofica di comunità meiobentoniche in relazione al contenuto ed alla composizione della sostanza organica particellata (Mar Ligure).Ph.D. Dissertation, Univ. Pisa, 246 pp.

Danovaro R. 1996. Detritus-bacteria- meiofauna interactions in a seagrass bed (Posidonia oceanica) of the NW Mediterranean. Mar. Biol. 127: 1-13. http://dx.doi.org/10.1007/BF00993638

Danovaro R. D., Marrale D., Della croce N., et al. 1999. Biochemical composition of sedimentary organic matter and bacterial distribution in the Aegean Sea trophic state and pelagic-benthic coupling. J. Sea Res. 42: 117-129. http://dx.doi.org/10.1016/S1385-1101(99)00024-6

Debenay J.-P., Tsakiridis E., Soulard R., et al. 2001. Factors determining the distribution of foraminiferal assemblages in Port Joinville Harbor (Ile d'Yeu, France): the influence of pollution. Mar. Micropaleontol. 43: 75-118. http://dx.doi.org/10.1016/S0377-8398(01)00023-8

Dell'anno A., Mei M. L., Pusceddu A., et al. 2002. Assessing the trophic state and eutrophication of coastal marine systems: a new approach based on the biochemical composition of sediment organic matter. Mar. Pollut. Bull. 44: 611-622. http://dx.doi.org/10.1016/S0025-326X(01)00302-2

Devi S.D., Rajashekhar K.P. 2009. Monsoon related Flux in Intertidal Foraminiferal diversity on the West Coast of India. Int. J. Ecol. Env. Sci. 35(4): 343-357. 
Diz P., Francés G., Costas S., et al. 2004. Distribution of benthic foraminifera in coarse sediment, Ría de Vigo, NW Iberian margin. J. Foraminif. Res. 34: 258-275 http://dx.doi.org/10.2113/34.4.258

Dubois M., Gilles K.A., Hamilton J.K., et al. 1956. Colorimetric method for determination of sugars and related substances. Anal. Chem. 28: 350-356. http://dx.doi.org/10.1021/ac60111a017

Fabiano M., Danovaro R., Fraschetti S. 1995. A three-year time series of elemental and biochemical composition of organic matter in subtidal sandy sediments of the Ligurian Sea (Northwestern Mediterranean). Cont. Shelf. Res. 15: 1453-1469. http://dx.doi.org/10.1016/0278-4343(94)00088-5

Frontalini F., Coccioni R. 2012. Benthic foraminifera as bioindicators of pollution: a review of Italian research over the last three decades. Rev. Micropaleontol. 54: 115-127. http://dx.doi.org/10.1016/j.revmic.2011.03.001

Goldstein S.T., Corliss B.H. 1994. Deposit feeding in selected deepsea and shallow-water benthic foraminifera. Deep-Sea Res. Part I Oceanogr. Res. Pap. 41: 229-241. http://dx.doi.org/10.1016/0967-0637(94)90001-9

Gooday A.J. 1992. The role of benthic foraminifera in deep seafood webs and carbon cycling. Eur. J. Protistol. 28: 341

Gooday A.J. 2003. Benthic foraminifera (Protista) as tools in deepwater palaeoceanography: environmental influences on faunal characteristics. Adv. Mar. Biol. 46: 1-90. http://dx.doi.org/10.1016/S0065-2881(03)46002-1

Hammer Ø., Harper D.A.T., Ryan P.D. 2001. PAST: Paleontological Statistics software package for education and data analysis. Palaeontol. Electron. 4: 1-9.

Horton B.P., Edwards R.J., Lloyd J.M. 1999. U.K. intertidal foraminiferal distributions: implications for sea-level studies. Mar. Micropaleonotol. 36: 205-223. http://dx.doi.org/10.1016/S0377-8398(99)00003-1

Jorissen F.J., Fontanier C., Thomas E. 2007. Chapter Seven Paleoceanographical Proxies Based on Deep-Sea Benthic Foraminiferal Assemblage Characteristics. Dev. Mar. Geol. 1: 263-325. http://dx.doi.org/10.1016/S1572-5480(07)01012-3

Kroencke I., Vanreusel A., Vincx M., et al. 2000. Different benthic size-compartments and their relationship to sediment chemistry in the deep Eurasian Arctic Ocean. Mar. Ecol. Prog. Ser. 199: $31-41$. http://dx.doi.org/10.3354/meps199031

Lee J.J., Muller W.A. 1973. Trophic dynamics and niches of saltmarsh foraminifera. Am. Zool. 13: 215-223.

Lipps J.H. 1983. Biotic interactions in benthic foraminifera. In: Trevesz M.J.S., McCall P.L. (eds), Biotic interactions in recent and fossil benthic communities. Plenum Press, New York, pp. 331-376. http://dx.doi.org/10.1007/978-1-4757-0740-3_8

Lipps J.H. 1988. Predation on foraminifera by coral reef fish: Taphonomic and evolutionary implications. Palaios 3: 315-326. http://dx.doi.org/10.2307/3514660

Linke P., Lutze G.F. 1993 Microhabitat preferences of benthic foraminifera-a static concept or a dynamic adaption to optimize food acquisition? Mar. Micropaleontol. 20: 215-234. http://dx.doi.org/10.1016/0377-8398(93)90034-U

Loeblich A.R Jr., Tappan H. 1987. Foraminiferal Genera and Their Classification, Von Nostrand Rinhold, New York. 970 pp.

Lowry O.H., Rosenbrough N.J., Farr A.L., et al. 1951. Protein Measurement with the Folin Phenol Reagent. J. Biol. Chem. 193: $265-275$.

Lorenzen C., Jeffrey J. 1980. Determination of chlorophyll in seawater. Tech Pap. Mar. Sci. (UNESCO) 35: 1-20.

Murray J.W. 1991. Ecology and paleoecology of benthic foraminifera. Longman, Harlow, 397 pp.

Murray J.W. 2001. The niche of benthic foraminifera, critical thresholds and proxies. Mar. Micropaleont. 41: 1-7. http://dx.doi.org/10.1016/S0377-8398(00)00057-8

Murray J.W., Alve E. 1999. Natural dissolution of modern shallow water benthic foraminifera: taphonomic effects on the palaeoecological record: Palaeogeogr. Palaeoclimatol. Palaeoecol. 146: 195-209. http://dx.doi.org/10.1016/S0031-0182(98)00132-1

Murray J.W., Alve E. 2000. Major aspects of foraminiferal variability (standing crop and biomass) on a monthly scale in an intertidal zone. J. Foraminif. Res. 30: 177-191. http://dx.doi.org/10.2113/0300177

Murray J.W., Bowser S.S. 2000. Mortality protoplasm decay rate, and reliability of staining techniques to recognise 'living' foraminifera: a review. J. Foraminif. Res. 30: 66-70. http://dx.doi.org/10.2113/0300066

Myers E. 1943. Life activities of foraminifera in relation to marine ecology. Am. Philos. Soc. Proc. 86: 439-458.

Nigam R., Saraswat R., Panchang R. 2006. Application of foraminifers in ecotoxicology: retrospect, perspect and prospect. Environ. Int. 32: 273-283. http://dx.doi.org/10.1016/j.envint.2005.08.024

Pusceddu A. 1997. Origin, biochemical composition and fate of organic matter in marine environments with different trophic state. Ph.D. Dissertation. University of Genova, 173 pp.

Pusceddu A., Dell'Anno A., Fabiano M. 2000. Organic matter composition in coastal sediments at Terra Nova Bay (Ross Sea) during summer 1995. Polar Biol. 23: 288-293. http://dx.doi.org/10.1007/s003000050446

Pusceddu A., Dell'Anno A., Danovaro R., et al. 2003. Enzymatically hydrolyzable protein and carbohydrate sedimentary pools as indicators of the trophic state of 'detritus sink' systems: a case study in a Mediterranean coastal lagoon. Estuaries 26: 641-650. http://dx.doi.org/10.1007/BF02711976

Pusceddu A., Gambi C., Manini E., et al. 2007. Trophic state, ecosystem efficiency and biodiversity of transitional aquatic ecosystems: analysis of environmental quality based on different benthic indicators. Chem. Ecol. 23: 1-11. http://dx.doi.org/10.1080/02757540701760494

Pusceddu A., Dell'Anno A., Fabiano M., et al. 2009. Quantity, biochemical and bioavailability of sediment organic matter as complementary signature of benthic trophic status. Mar. Ecol. Prog. Ser. 375: 41-52 http://dx.doi.org/10.3354/meps07735

Pusceddu A., Bianchelli S., Sanchez Vidal A., et al. 2010. Organic matter in sediments of canyons and open slopes in the Eastern Atlantic and Mediterranean continental margins. Deep-Sea Res. I 57(3): 441-445 http://dx.doi.org/10.1016/j.dsr.2009.11.008

Pusceddu A., Della Patrona L., Beliaeff B. 2011. Trophic status of earthen ponds used for semi-intensive shrimp (Litopenaeus stylirostris, Stimpson, 1874) farming in New Caledonia (Pacific Ocean). Mar. Environ. Res. 72: 160-171. http://dx.doi.org/10.1016/j.marenvres.2011.07.005

Qvale G., Van Weering T.C.E. 1985. Relationship of surface sediments and benthic foraminiferal distribution patterns in the Norwegian Channel, Northern North Sea. Mar. Micropaleontol. 9: 469-488. http://dx.doi.org/10.1016/0377-8398(85)90014-3

Schafer C.T., Collins E.S., Smith J.N. 1991. Relationship of foraminifera and thecamoebian distributions sediments contaminated by pulp mill effluent: Saguenay Fjord, Quebec, Canada. Mar. Micropaleontol. 17: 255-283. http://dx.doi.org/10.1016/0377-8398(91)90016-Y

Schafer C.T., Winters G.V., Scott D.B., et al. 1995. Survey of living foraminifera and polychaete populations at some Canadian aquaculture sites: potential for impact mapping and monitoring. J. Foraminif. Res. 25: 236-259. http://dx.doi.org/10.2113/gsjfr.25.3.236

Scott D.B., Medioli F.S. 1980. Living vs. total foraminifera populations: their relative usefulness in palaeoecology: J. Paleontol. 54: 814-831.

Setty M.G.A.P., Nigam R. 1982. Foraminiferal assemblages and organic carbon relationship in benthic marine ecosystem of Western Indian continental shelf. Indian J. Mar. Sci. 11: 225-232.

Strickland J.D.H., Parsons T.R. 1972. A practical Handbook of seawater analysis. Bull. Fish. Res. Bd Canada 167: 310 pp.

Walton W.R. 1952. Techniques for recognition of living Foraminifera. Contribution from the Cushman Foundation the Foraminiferal Research 3: 56-60.

Welker C.E., Sdrigotti S., Covelli J., et al. 2002. Microphytobenthos in the Gulf of Trieste (Northern Adriatic Sea): Relationships with Labile Sedimentary Organic Matter and Nutrients. Estuar. coast. Shelf Sci. 55: 259-273. http://dx.doi.org/10.1006/ecss.2001.0901

Wiggert J.D., Hood R.R., Banse K., et al. 2005. Monsoon driven biogeochemical processes in the Arabian Sea. Prog. Ocean. 65: 176-213.

http://dx.doi.org/10.1016/j.pocean.2005.03.008 